\title{
Principals' perspectives on key factors that contribute to sustainable quality education
}

\author{
Jan Heystek and Lorinda Minnaar
}

\begin{abstract}
This article reports on the perspectives of principals about factors, which have an influence on their work to provide quality education for all children. Principals in the Western Cape were asked to rate key factors that contribute to sustainable quality education in their schools. An online survey was implemented as the data collection instrument and the FREQ procedure was followed to analyse the raw data statistically. The results showed that dedicated and well-qualified teachers who teach disciplined learners in a safe environment should receive priority in any action principals and Departments of Education take to improve and sustain the quality of education in the Western Cape and possibly in all South African schools.
\end{abstract}

\section{Introduction}

The delivery of sustainable quality education for all continues to be an ideal aspired to and pursued by many countries including South Africa. Since South Africa's first democratic election in 1994, government has focused on transforming education and has concentrated its efforts on achieving equitable and sustainable quality education in schools, largely through the introduction of new curricula and amendments to education legislation and policy. Government has also introduced and implemented various programmes, guidelines and action plans in its commitment to both improving and ensuring sustainable quality education. Among these are: the new Sector Plan, which encapsulates government's response to the priorities, targets and programmes articulated in the National Development Plan - 2030 (2015, p.50), the National Policy on Whole School Evaluation (2001, p.3), the Delivery Agreement for the Basic Education Sector, Outcome 1 - Improved Quality of Basic Education (2010, pp.1-4) and the Guidelines Relating to Planning for Public School Infrastructure (2012).

In the Basic Education Budget Vote Speech for the 2015/16 financial year delivered by the Minister of Basic Education at the National Assembly in 
Cape Town on 06 May 2015, Mrs A M Motshekga reiterated the important role that quality basic education plays in a nation's current and future prosperity, development and growth. She also articulated government's intention to improve the overall quality of education in South African schools:

\footnotetext{
Our focus is to reposition the Sector to deliver on the mandate for quality and efficient schooling in the 2015/2016 financial year. We remain resolute in our quest to improve quality and efficiency throughout the schooling Sector, with a renewed emphasis on curriculum coverage, improving assessment and strengthening quality, efficiency and accountability in our schools, districts and provinces, as well as in our administrative departments and sectoral partnerships (Motshekga, 2015).
}

Sustaining quality education, particularly in under-resourced schools, may present a challenge that leaves education officials and policy writers overwhelmed by the many competing priorities and pressing educational needs that simultaneously demand their urgent attention. We acknowledge the existence of a multiplicity of contextual factors that could improve and contribute to sustainable quality education and we argue that it is important for role-players in education to reach consensus on which of these needs (factors) merit urgent attention and ought to be prioritised for budget allocations.

In the South African school system, public schools are divided into five quintiles depending on the poverty of the community around the school, as well as on certain infrastructural factors. Quintile 1, 2 and 3 schools do not charge school fees, are termed 'no-fee' schools and appear to be located in poorer socio-economic contexts, while Quintile 4 and 5 schools charge school fees and appear to be located more within middle-class to affluent contexts (Western Cape Education Department, 2013). Our research assumption was that we would obtain different data from respondents from the five quintiles. Our assumption was, amongst other, supported by information gleaned from Table 14 of the National Senior Certificate Technical Report (2013, p.72), which indicates that Quintile, 1, 2 and 3 schools appear to struggle to meet the same standards of academic quality as Quintile 4 and 5 schools do, particularly in regard to Grade 12 (Matric) results.

This article reports on quality education, one of seven themes, which comprised a large-scale, exploratory, quantitative, online survey with the title 'School Governance and Leadership for Sustainable Education for All', which we undertook in public schools in the Western Cape. In the online survey, we 
explored the ability of principals and parent members of school governing bodies to fulfil their various roles and functions as governors. For the purposes of this article, we discuss only 11 factors, which we selected for our study specifically because our area of interest is school governance and management and these factors are governed and managed by principals and school governing bodies. The aim of this article is to show which of the factors school principals perceive as key to sustaining quality education in their schools and to explore if there are any differences in the perspectives of principals from different quintile schools about the factors, which contribute to sustainable quality education. We are of the opinion that school principals are well placed to offer useful insights into these key factors and although we did not include leadership as a key factor, we acknowledge that leadership is important because we specifically gathered data concerning the key factors from principals, who are school leaders.

\section{The conceptual challenge: defining 'quality education'}

A problem with which some scholars and role-players in education may grapple is "How do we define quality education?" Tikly $(2011$, p.3) asserts that the difficulties in developing a sense of what quality education encompasses are compounded by the fact that there is no universally accepted definition of education quality. Consequently, we deduce that the main hindrance to defining quality education is that notions of, discourses on and approaches to quality are embedded in the multidimensional education systems of developed and developing countries globally. Nevertheless, literature alludes to factors, which seem to contribute to quality education in most, if not all countries and contexts.

In 2000, the United Nations Educational, Scientific and Cultural Organisation (UNESCO) organised the World Education Forum in Dakar, Senegal to identify six measurable goals that would comprise the Dakar Framework for Action and Millennium Development Goals. Goal 6 of the Dakar Framework for Action explicitly aimed at improving the quality of education globally, particularly the quality of literacy, numeracy and life skills. Its expanded definition of quality set out desirable characteristics such as healthy, motivated students, processes such as competent teachers using active pedagogies, content in terms of relevant curricula and systems such as good governance and equitable resource allocation (Education for All Global 
Monitoring Report, Chapter 1, 2005, p.29). The report (2005) also makes a strong case for safety and support of learners as a quality imperative within a human rights approach to quality education. School effectiveness studies conducted in industrialised countries identified strong educational leadership, the acquisition of basic skills, an orderly and secure teaching and learning environment, high learner expectations and regular assessment of learners' work as salient factors that contribute to quality education.

\section{Introducing of key factors}

The key factors, which we selected for our study included dedicated teachers, well-qualified teachers, disciplined learners, safe schools, a relevant curriculum, involved parents, sufficient teaching and learning resources, small classes, well-maintained facilities and good infrastructure, sufficient furniture for learners and a comprehensive extra-mural programme.

Miller (2012, p.36) asserts that the six essential affective characteristics of dedicated teachers are enthusiasm, encouragement, humour, interest, mental health and availability. In South Africa, a dedicated teacher ought to fit the profile of a professional person outlined in the Code of Professional Ethics of the South African Council of Educators (SACE) (2000). The Code of Professional Ethics calls educators to acknowledge the noble calling of their profession and to acknowledge that the attitude, dedication, self-discipline, ideals, training and conduct of the teaching profession determine the quality of education in this country $(2000, \mathrm{p} .1)$.

In regard to teacher qualifications, findings that emerged from a comparative study conducted by Carnoy, Chisholm and Chilisa (2012, p.151) of Grade 6 Mathematics teachers in Botswana and North-West Province of South Africa, showed that learners' poor performance and low scores in Mathematics tests were related directly to inadequately qualified teachers. In South Africa, teachers' lack of appropriate qualifications seriously threatens the delivery of sustainable quality education in many schools. In response to a Democratic Alliance (DA) parliamentary probe by Annette Lovemore (SA Breaking News, 2014), a spokesperson for the Department of Basic Education (DBE) admitted that there were approximately 10725 unqualified or under-qualified teachers in public schools in 2013. The implication is that unqualified or under-qualified teachers may negatively affect learners' learning and lives 
with the implication that a significant number of learners are not receiving quality education. Further, the Executive Summary published by the Centre for Development and Enterprise (2015, p.4) shows that in South Africa there is a severe shortage of teachers who are qualified to teach in the Foundation Phase. There is also a significant shortage of teachers qualified to teach languages in all phases, Mathematics in the Intermediate and Senior phases, and Mathematical Literacy in the Further Education and Training (FET) Phase, all of which has a negative effect on the delivery of sustainable quality education.

Ming Chiu and Wing Yin Chow (2011, p.517) advance the notion that variables such as the economic and cultural contexts of different countries, characteristics of schools and family values potentially shape learners' discipline and their relationships with teachers and one another. It follows that teachers have the ability to enhance the quality of education provided by their schools by maintaining a balance between their teaching and classroom management strategies. This will be possible if they reduce disruptive behaviour and distractions in the classroom on the one hand and challenge their learners academically by keeping them focused on and engaged in interesting learning activities, on the other.

In South Africa, some schools experience "violence that often leaves educators battling to cope with increasing demands for learner performance in the midst of an inherited culture of violence and intimidation that spills over into the classroom" (Bester and Du Plessis, 2010, p.203). Mestry and Khumalo (2012, p.102) provide evidence that many schools are not adopting and enforcing codes of conduct owing to the limited knowledge, skills and experience of legislation of many parents serving on governing bodies. Despite the introduction of numerous legal measures to ensure learner safety at schools, the culture of violence afflicting many communities in South Africa appears to make it extremely difficult for teachers to meet the increasing demands on them to ensure that learners perform well (Bester and Du Plessis 2010, p.203).

In respect of the importance of having a relevant curriculum, UNESCO's General Education Quality Analysis/Diagnosis Framework (GEQAF) (2015) states:

A good curriculum plays an important role in forging life-long learning competencies, as well as social attitudes and skills, such as tolerance and respect, constructive management of 
diversity, peaceful conflict management, promotion and respect of Human Rights, gender equality, justice and inclusiveness. At the same time, curriculum contributes to the development of thinking skills and the acquisition of relevant knowledge that learners need to apply in the context of their studies, daily life and careers.

It is important, therefore, that developing countries design their own relevant curricula that cater for and respond to the needs and priorities of learners, their families and communities optimally (Education for All Global Monitoring Report, 2005, p.31). According to the EdQual Policy Brief No. 10 (2010, p.3), "Coherence in aims and content within and between phases of the curriculum is key." In South Africa, a single, comprehensive Curriculum and Assessment Policy document (CAPS) (2011) was developed for each subject offered at schools (Available online:

http://www.education.gov.za/Curriculum/NCSGradesR12/tabid/419/Default.a spx). The National Curriculum Statement Grades R-12 lists the knowledge, skills and values worth learning in South African schools and aims to ensure that children acquire and apply knowledge and skills in ways that are meaningful to their own lives. It can therefore be said that the curriculum promotes knowledge in local contexts while being sensitive to global imperatives (National Curriculum Statement, 2011, p.4).

Findings that emanated from Jeynes's (2005) meta-analysis, which examined the relationship between parental involvement and the academic achievement of urban elementary school children indicate that parental involvement enjoys an influence that largely transcends differences in socio-economic status, race and other factors. This is supported in the parental involvement data for racial minorities and by gender, which is encouraging in that any group can experience the advantages of parental involvement. However, one of the findings that emerged from a study undertaken by Motala and Luxomo (2014, p.95) evidences the fact that although South African policy favours parental involvement, parents of learners attending poor urban and rural schools in Gauteng and the Eastern Cape hesitate to become involved in the education of their children owing to their lack of self-efficacy.

There is no certainty about the actual direct influence of small classes on academic outcomes although there is a perception that small classes are advantageous to children's school results. Some scholars anticipate the economic ramifications by raising questions regarding the cost effectiveness of small classes while others argue that small classes need to be considered a key feature of educational policy (Blatchford, Bassett and Brown, 2011, 
p.715). Similarly, Ehrenberg, Brewer, Gamoran and Willms (2001, p.1) contend that the number of learners in a class can potentially affect the quantity and quality of time a teacher is able to devote to learners' individual needs, the quantity and quality of content that a learner learns in class and their level of social engagement and interaction.

Xaba (2012, p.215) asserts that the significance of facilities maintenance to school functionality is recognised worldwide to the extent that international studies report numerous education departments have organisational structures or units specifically dedicated to managing and maintaining school facilities. In terms of Section 20(1)(g) of the South African Schools Act, No 84 of 1996, the school governing body must "Administer and control the school's property, buildings and grounds occupied by the school, including school hostels, if applicable.” In South Africa, school governing bodies are responsible for maintaining school facilities and for providing a good infrastructure within which quality teaching, learning and extra-mural activities can occur.

Hassell (2011, p.18) asserts classroom space and furniture needs to be flexible to enable teaching and learning by means of teacher-directed instruction, selfstudy, group work, oral presentations, peer instruction and interaction and class discussions. It is disconcerting that in many South African schools, particularly in the rural areas of the poorer provinces, such as in the Eastern Cape, schools lack adequate desks and chairs for learners. John's report in the Mail and Guardian (2012) relates how "Eastern Cape learners sit on empty mealiemeal sacks, beer crates or bricks, bending over double as they attempt to write in their exercise books. Yet they are the lucky ones - some pupils have to sit on bare floors."

In most South African schools, dedicated teachers take on additional responsibilities emanating from their schools' extra-mural programme. Many learners, in addition to their core learning activities, participate in a wide range of extra-mural activities as part of their school day. Shulruf (2010, p.594) however, points out that numerous scholars, particularly in the United States, have undertaken studies concerning various aspects of extra-mural activities but none have established empirically a causal effect between extramural activities and educational outcomes. Dimech and Seiler (2011, p.348) view learners' participation in extra-mural activities from a social learning theory perspective and claim, "Participation in organised sport, particularly in team sport, may play an important role in a child's social development." 


\section{Research methodology}

\section{Paradigmatic approach}

For this study, we used a positivistic paradigm to understand the social phenomenon of quality education from the perspective of principals. To achieve our primary objective, we implemented a quantitative paradigmatic approach. According to Ivankova, Cresswell and Plano Clark (2007, p.255), the goal of quantitative research is to explain the trends or relationships between variables. By quantifying principals' responses to questions, which we posed in an online survey on quality education, we were able to identify trends in the principals' professional perspectives concerning the factors that contribute to sustainable quality education in their schools. Although the issues under investigation are difficult to quantify and as concepts, principals hold their own interpretation of the broad issues, the objective was to obtain an indication of the importance of the specific factors linked to quality education.

\section{Population and sample selection}

In light of our research assumption, we required access to the total population of school principals across the five quintiles in the Western Cape. Therefore, our sample can be described as large and purposive because it comprised principals of all the public primary and secondary schools in the Western Cape, a total of 1433 respondents. According to Grinnell and Unrau (2008); Monette, Sullivan and De Jong (2005), the sample was purposive because it comprised elements, namely school principals, that contained the most characteristic, representative or typical attributes of the population.

Data collection instrument: an online survey

An online survey was used to collect data, as described and discussed previously by Minnaar and Heystek (2013). In the specific question on quality education on which this article reports, all respondents, namely school principals from no-fee and fee charging schools within the five quintiles received the same question. They were asked to rate, on a 4-point scale, to what extent they strongly disagreed, agreed or strongly agreed that selected 
factors contribute to the provision of sustained quality education in their schools.

Although there are advantages to using online surveys, for example, as Evans and Mathur (2005, p.196) mention that online surveys are able to reach participants who have Internet access throughout the world, that large samples can be reached and with the Internet these surveys can be managed in a time efficient manner, there was a very low return rate. Even after it was established that all schools in the Western Cape were supposed to have functional e-mail addresses, the return of 181 questionnaires was acceptable, yet very low.

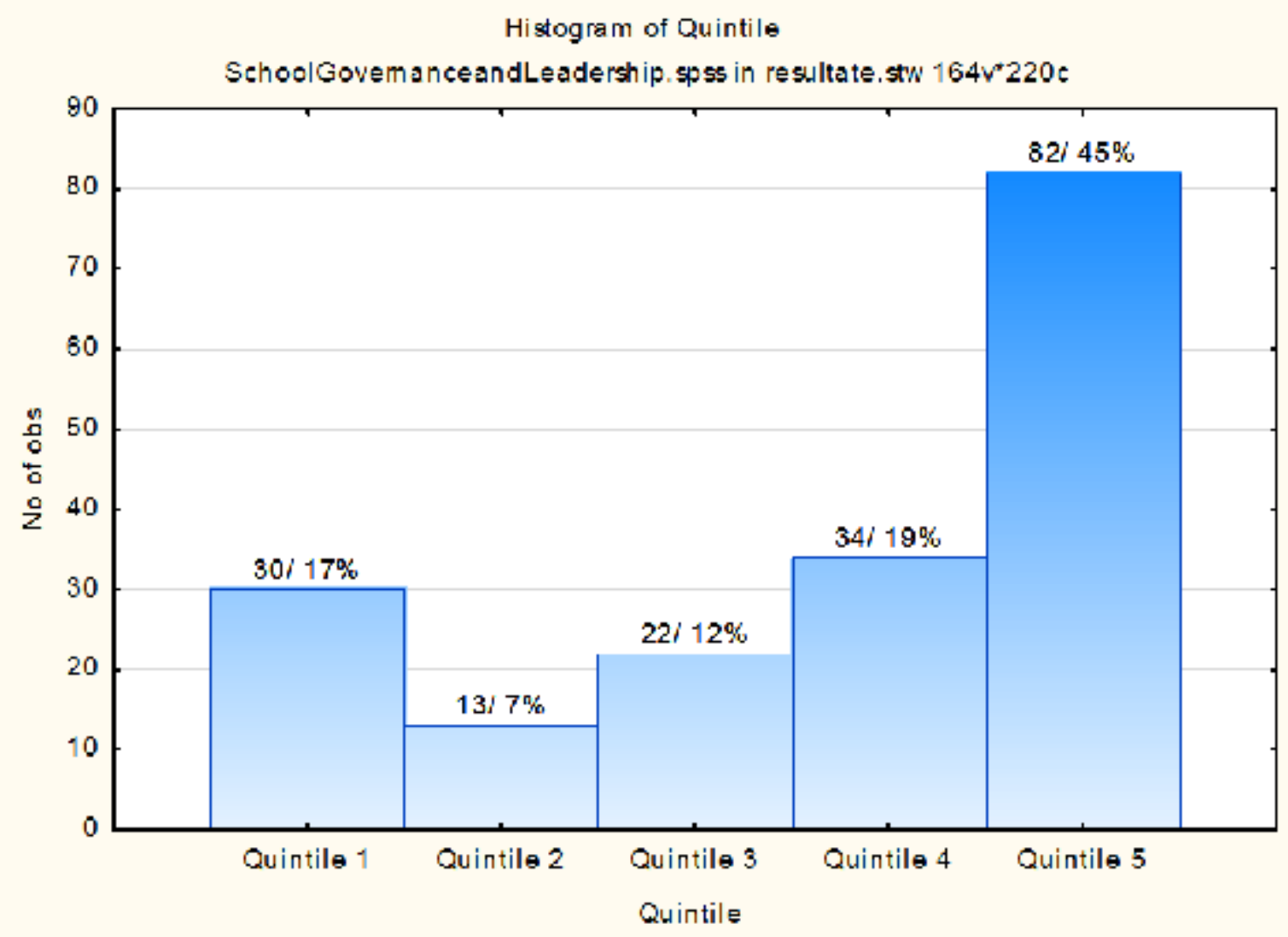

Figure 1: Principals' responses per quintile

Even with a specific effort to get more responses from Quintile 1, 2 and 3 schools, they still had the lowest response rate. The total number of these schools, namely $65(36 \%)$ may provide us with some indications on how these principals experience the factors which provide quality education. 


\section{Quantitative data analysis}

The statistician conducted a quantitative analysis of all the collected raw data by means of the FREQ procedure. According to SAS/STAT® Version 9.1 User's Guide (2004, p.1431) the FREQ procedure provides easy access to statistics for testing contingency tables. For the purposes of the survey question on which this article reports, the frequency with which the school principals responded to the eleven factors that contribute to sustainable quality education by clicking the 'strongly agree' rating option, was calculated statistically as a response percentage. Only the 'strongly agree' responses were calculated and used for this article because they obtained the highest response percentages and were therefore statistically significant.

\section{Validity and reliability}

According to Babbie and Mouton (2009, p.122), "validity refers to the extent to which and empirical measure adequately reflects the real meaning of the concept under consideration." Further, Babbie and Mouton (2009, p.119) explain reliability as "a matter of whether a particular technique, applied repeatedly to the same object, would yield the same result each time." The validity and reliability of the rating scale question, which we posed to school principals to generate data was established by means of the Cronbach Coefficient Alpha. Cronbach's coefficient alpha estimates the reliability of a scale by determining the internal consistency of the test or the average correlation of items within the test (Cronbach, 1951). The rating scale question scored $\alpha=0.920035$, an indication of excellent internal consistency.

\section{Ethical considerations}

We applied to Stellenbosch University's Ethics Committee for ethical clearance for the study, which was granted subsequent to the submission of required documentation. The Western Cape Education Department's (WCED) Research Directorate approved the study and granted us consent to conduct the study. 


\section{Results}

Table 1 (below) shows the principals' 'Strongly Agree' responses to factors that contribute to sustainable quality education per quintile.

Table 1: Principals' 'Strongly Agree' responses to factors that contribute to sustainable quality education per quintile

\begin{tabular}{|l|c|c|c|c|c|}
\hline \multicolumn{1}{|c|}{ Factors for quality education } & \multicolumn{5}{c|}{ Quintiles as \% } \\
\hline & $\mathbf{1}$ & $\mathbf{2}$ & $\mathbf{3}$ & $\mathbf{4}$ & $\mathbf{5}$ \\
\hline Dedicated teachers & 79 & 85 & 82 & 97 & 93 \\
\hline Well-qualified teachers & 79 & 92 & 77 & 91 & 82 \\
\hline Disciplined learners & 69 & 84 & 77 & 91 & 84 \\
\hline A safe school & 72 & 92 & 80 & 82 & 82 \\
\hline A relevant curriculum & 72 & 85 & 64 & 91 & 84 \\
\hline Involved parents & 69 & 85 & 77 & 94 & 76 \\
\hline Sufficient teaching and learning resources & 76 & 62 & 68 & 86 & 78 \\
\hline Small classes & 66 & 69 & 55 & 76 & 77 \\
\hline Well-maintained facilities and good infrastructure & 66 & 69 & 73 & 76 & 70 \\
\hline Sufficient furniture for learners & 66 & 62 & 59 & 76 & 62 \\
\hline A comprehensive extra-mural programme & 62 & 54 & 62 & 74 & 54 \\
\hline Average \% per quintile & 71 & 76 & 70 & 85 & 77 \\
\hline
\end{tabular}

There does not appear to be significant differences between the opinions of the principals from the different quintiles. Principals from the poorer quintiles feel less strongly about these factors, but do not differ much from the Quintile 5 school principals. This survey does not make provision to explain the differences, but the potential implications thereof will be discussed.

In Figure 2 (below), we present all the principals' 'strongly agree' response percentages to the eleven key factors that contribute to sustainable quality education. The response percentages have been arranged graphically in columns from the factor that achieved the highest response percentage to the factor that obtained the lowest response percentage. 


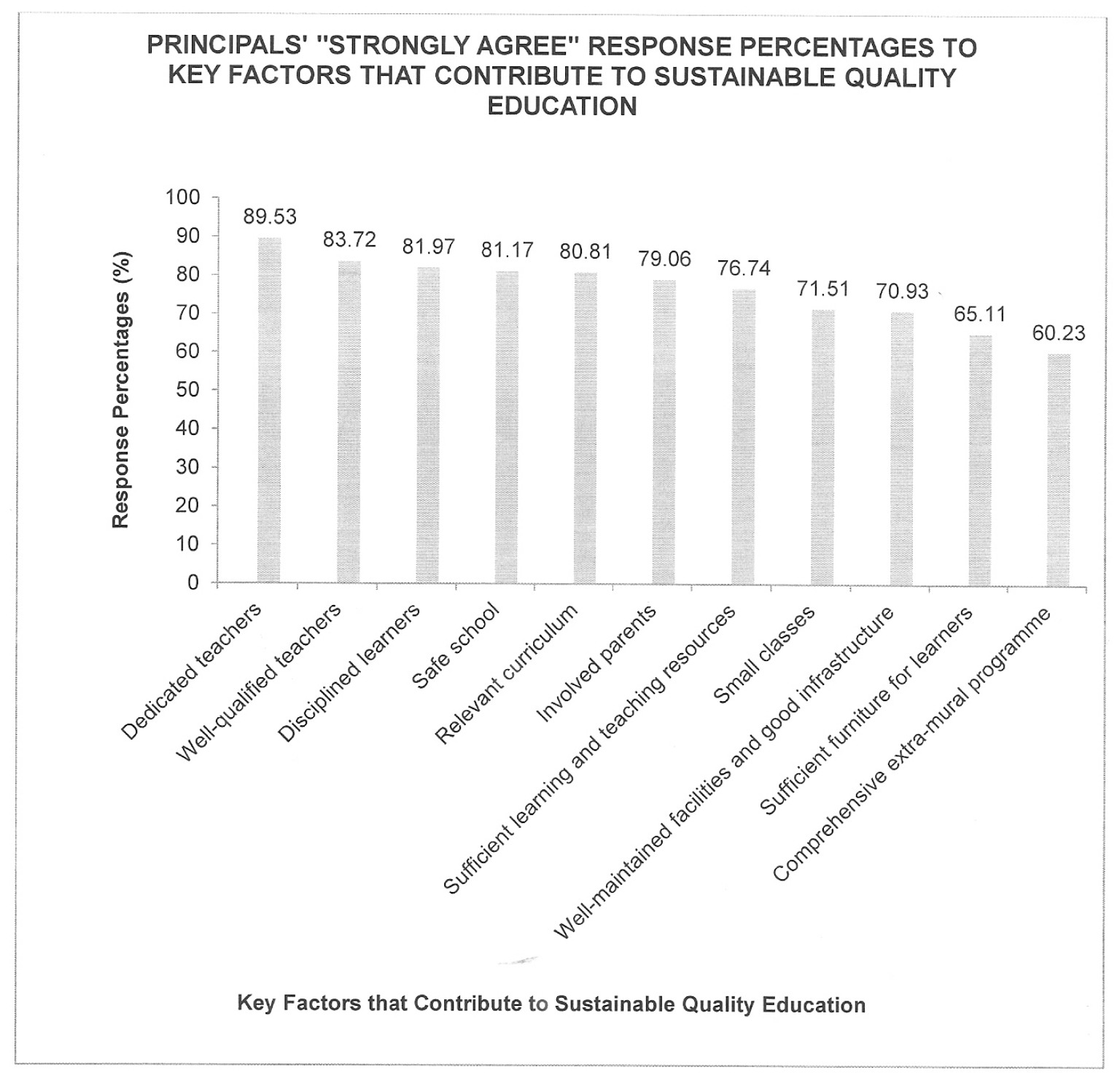

Figure 2: Principals' 'strongly agree' response percentages to key factors that contribute to sustainable quality education

Overall, there is a 'Strong Agreement' about all the factors. The importance of the data is therefore, to obtain an indication, which is possibly more important, although all the factors are important to provide quality education. Individual schools or departments of education may use the data to prioritise their actions to improve the quality of education. The three key factors, which obtained the highest response percentages, see people as key factors contributing to sustainable quality education, whereas the factors that obtained the five lowest response percentages focus on structural aspects.

Principals clearly indicated that dedicated as well as well-qualified teachers are the two factors that most contribute to sustainable quality education in 
their schools. The EdQual Policy Brief No. 10 (2010, p.3) states that suitably trained and motivated teachers are a "quality input" of quality education. Similarly, Mart (2013, p.437) asserts:
Passion matters in that it motivates and inspires the teachers. Passion is a motivational factor that affects teacher performance. It drives the teachers for a better student accomplishment. Passionate teachers create an effective learning environment and increase learning potential of students. Passion leads to creativity; therefore, passionate teachers have the ability to think and produce new notions in an easy way. Passionate teachers are committed and dedicated to their schools and a good education achievement is an outcome of this commitment and dedication.

Therefore, dedicated teachers are more motivated to develop themselves, which has a more direct and positive effect on the quality of education. Findings that emerged from a study by Heystek and Terhoven (2015, p.13-p.14) show that dedicated teachers are passionate about teaching and are motivated intrinsically to participate in professional development programmes, thereby empowering themselves and developing their personal and professional knowledge and skills that will benefit not only themselves, but more importantly their learners, schools and communities. Although Quintile 5 schools perhaps are able to provide more professional development opportunities for their teachers because they are situated in wealthier areas than schools in the lower quintiles, all the principals strongly agreed that it is important to have well-qualified teachers.

Principals' 'strongly agree' responses to disciplined learners and safe schools confirm the importance of an orderly and harmonious teaching and learning environment. This finding is supported in literature by the findings of Luiselli,Putnam, Handler and Feinberg (2005, p.185), who assert, "when teachers are able to increase, strengthen, and maintain high levels of student academic engagement, there is a corresponding improvement in academic performance and achievement." Le Roux and Mokhele (2011) collated findings that reveal that violence in schools is brought about by dysfunctional family structures, the presence of gangs and weapons and the distribution of harmful substances, such as alcohol and drugs, all of which affect learner performance adversely. However, even the most conservative code of conduct will not contribute to a safe school if it is not enforced consistently. Mestry and Khumalo (2012) provide evidence that many schools are not adopting and enforcing codes of conduct because of the limited knowledge, skills and experience of legislation of many parents on the governing bodies. 
A relevant curriculum can be linked positively to dedicated and well-qualified teachers as well as to disciplined learners because such teachers can make the curriculum relevant, which will in turn ensure learners become better disciplined when they realise the importance of the curriculum and of their education. Lumadi (2014, p.15) avers, "The efforts to create good schools will depend entirely on the quality of our curriculum, for a quality curriculum responds to the needs of the learners and the country in large." Lumadi (2014, p.14) also refers to the important role played by dedicated and well-qualified teachers by maintaining that, "If schools worldwide are to meet the challenge of educating increased numbers of children with diverse needs, teachers must embrace instruction and curricula that engage and encourage all students."

Although involved parents are a people-orientated factor, it surprisingly obtained only the sixth response percentage of the eleven key factors. Despite the findings of Fan and Chen (2001), which point to a strong relationship between parental involvement and academic outcomes, the results indicate that principals in this sample regard involved parents somewhat less important than dedicated teachers, well-qualified teachers and disciplined learners as contributors to sustainable quality education in their schools. One explanation for this finding may be that involved parents is an 'out-of-school' factor, whereas dedicated teachers, well-qualified teachers and disciplined learners are school-based factors and principals may have more control over these last mentioned factors.

The last five factors can be linked to structural factors. Although the Western Cape Education Department indicated the need to build more schools and that there are numerous problems with infra-structure and facilities, specifically in Quintile 1, 2 and 3 schools, these principals still rate the human factor, that is teachers, as the more important factor in the provision of quality education. This could be an important issue for departments of education because they may prioritise more funds to develop teachers rather than to provide state-ofthe-art facilities for all schools.

Sufficient teaching and learning resources was the factor that obtained the seventh response percentage. One would expect this factor to have obtained a higher response percentage considering the consternation in the South African media surrounding the delivery, and at times non-delivery, of stationery and textbooks evokes at the beginning of each new school year since the notorious 'Text-Book Saga' in 2012 (Veriava, 2013). However, it should be borne in mind that $45 \%$ of the respondents who responded to our rating scale question 
on factors that contribute to sustainable quality education were principals of Quintile 5 schools. Quintile 5 schools do not appear to struggle with nondelivery of teaching and learning resources as some Quintile 1, Quintile 2 and Quintile 3 schools that are located in poor urban and rural areas do.

Small classes was the factor that obtained the eighth response percentage, indicating that although principals may be well aware of the academic benefits of small classes as espoused in literature, such as the assertions of Finn and Suriani (2007), they accord more importance to the contributions of people to the delivery of sustainable quality education in their schools. Their line of reasoning may be that teaching a large class of well-disciplined learners will not present an insurmountable challenge to a teacher who is both well-qualified and dedicated in a school where there are sufficient teaching and learning resources.

The response percentage for well-maintained facilities and good infrastructure placed this factor in ninth position overall. It appears that although principals acknowledged that having well-maintained school facilities with a good infrastructure is important, it is not absolutely essential for the delivery of sustainable quality education.

Principals' response percentages placed sufficient furniture for learners in the tenth position. This low position was surprising, particularly in terms of the poorer Quintile 1, 2 and 3 schools because there have been court cases between parents of various schools and the Eastern Cape Province (High Court of South Africa, Eastern Cape Local Division, Mthatha, Case no. 2144/2012) over failure to provide essential school furniture. From this result, it appears that insufficient furniture for learners does not warrant urgent attention in Western Cape schools, as in certain other provinces of South Africa.

A comprehensive extra-mural programme was the last placed factor in the eleventh position. This result was also unanticipated, this time in terms of Quintile 5 school principals who contributed the largest percentage of responses. It would appear that Quintile 5 principals attach little, if any significance to a comprehensive extra-mural programme as a factor, which contributes to sustainable quality education. Yet, findings that emerged from a study by Minnaar (2009) in schools previously categorised as 'Model C' schools, many of which now fall within the Quintile 5 category, showed that schools expect high commitment from teachers in terms of extra-mural 
programmes and that teachers spend a very high average of their time on extra-mural activities. The reasons provided by the participants for expecting high commitment from teachers in respect of extra-mural programmes was based on their desire for teachers to get to know learners in a context other than the academic context in the classroom.

\section{Conclusion}

It does not seem as if the socio-economic context of the schools affects principals' perspectives of the importance of specific factors, which may influence their own or their schools' performance. Structural factors undoubtedly contribute to sustainable quality education, but it seems as if factors relating to people are more important. Although there is a rank order of these factors, they are all important and they will affect the quality of education. Each school and district can determine which of these factors may be the most important for urgent attention to improve the quality at the local context.

Clearly though, dedicated and well-qualified teachers who teach disciplined learners in a safe environment should receive priority in any action principals and Departments of Education take to improve and sustain the quality of education in the Western Cape and possibly in all schools in all the provinces of South Africa.

\section{References}

Babbie, E. and Mouton, J. 2009. The practice of social research. Oxford University Press.

Bester, S. and Du Plessis, A. 2010. Exploring a secondary school educator's experiences of school violence: a case study. South African Journal of Education, 30: pp.203-229.

Blatchford, P., Bassett, P. and Brown, P. 2011. Examining the effect of class size on classroom engagement and teacher pupil interaction: differences in relation to pupil prior attainment and primary vs. secondary schools. Learning and Instruction, 21: pp.715-730. 
Carnoy, M., Chisholm, L. and Chilisa, B. 2012. The low achievement trap. Comparing schooling in Botswana and South Africa. http://www.hsrcpress.ac.za 12, April 2014.

Centre for Development and Enterprise. 2015. Teachers in South Africa: supply and demand 2013-2025. Available online: http://www.cde.org.za/teacher-supply-and-demand-2013-2025/

Cronbach, L.J. 1951. Coefficient alpha and the internal structure of tests. Psychometrika,16(3): pp.297-334.

Dimech, A.S. and Seiler, R. 2011. Extra-curricular sport participation: a potential buffer against social anxiety symptoms in primary school children. Psychology of Sport and Exercise, 12: pp.347-354.

Education for All - Global Monitoring Report. 2005. Understanding education quality.

EdQual Policy Brief No.10. 2010. A framework for education quality. November 2010. (Written by Tikly, L. and Barrett, A., University of Bristol).

Ehrenberg, R.G., Brewer, D.J., Gamoran, A. and Willms, J.D. 2001. Class size and student achievement. American Psychological Society, 2(1): pp.1-30.

Evans, J.R. and Mathur, A. 2005. The value of online surveys. Internet Research. 15(2): pp.195-219. Emerald Group Publishing Limited.

Fan, X. and Chen, M. 2001. Parental involvement and students' academic achievement: a meta-analysis. Educational Psychology Review, 13(1): pp.1-22.

Finn, J.D. and Suriani, A.E. 2007. Small classes in the early grades: one policy - multiple outcomes. Paper prepared for the National Invitational Conference of the Early Childhood Research Collaborative, sponsored by the University of Minnesota Center for Early Education and Development and the Federal Reserve Bank of Minneapolis. Minneapolis, MN, December 7-8, 2007.

Grinnell, R.M. and Unrau, Y.A. 2008. Social work research and evaluation: foundations of evidence-based practice. New York: Oxford University Press. 
Hassell, K. 2011. Flexible furnishings - adaptable furniture and classroom spaces will set up the 21-century student for success. American School \& University. ASUMAG. October: pp.18-19.

Heystek, J. and Terhoven, R. 2015. Motivation as critical factor for teacher development in contextually challenging underperforming schools in South Africa. Professional Development in Education, 41(4): pp.624-639. http://dx.doi.org/10.1080/19415257.2014.940628 pp.1-16.

Ivankova, N.V., Creswell, J.W. and Plano Clark, V.L. 2007. Foundations and approaches to mixed methods research. In Maree, K. (Ed.), First steps in research. Pretoria: Van Schaik.

Jeynes, W.H. 2005. A meta-analysis of the relation of parental involvement to urban elementary school student academic achievement. Urban Education, 40(3): pp.237-269.

John, V. 2012. Education in crisis: teaching floored by lack of chairs. Mail and Guardian. Available online:

http://mg.co.za/article/2012-10-19-00-teaching-floored-by-lack-of-chairs

Le Roux, C.S. and Mokhele, P.R. 2011. The persistence of violence in South African schools: in search of solutions. Africa Education Review, 8: pp.318-335.

Luiselli, J.K., Putnam, R.F., Handler, M.W. and Feinberg, A.B. 2005. Whole school positive behaviour support: effects on student discipline problems and academic performance. Educational Psychology: An International Journal of Experimental Educational Psychology, 25(2-3): pp.183-198.

Lumadi, M.W. 2014. Towards a responsive curriculum implementation. Inaugural lecture delivered by Prof Mutendwahothe Walter Lumadi from the Department of Curriculum and Instructional Studies, UNISA.

Mart, C.T. 2013. A passionate teacher: teacher commitment and dedication to student learning. International Journal of Academic Research in Progressive Education and Development, 2(1): pp.437-442. 
Mestry, R. and Khumalo, J. 2012. Governing bodies and learner discipline: managing rural schools in South Africa through a code of conduct. South African Journal of Education, 32: pp.97-110.

Miller, P. 2012. Ten characteristics of a good teacher. English Teaching Forum, Number 1. First published in Volume 25(1): (1987).

Ming Chiu, M. and Wing Yin Chow, B. 2011. Classroom discipline across forty-one countries: school, economic, and cultural differences. Journal of Cross-Cultural Psychology, 42: p.516.

Minnaar, L. 2009. The expectations of parent members of school governing bodies regarding teacher workload in South African schools. Unpublished $\mathrm{PhD}$. University of Pretoria.

Minnaar, L. and Heystek, J. 2013. Online surveys as data collection instruments in education research: a feasible option? South African Journal of Higher Education, 27(1): pp.162-183.

Monette, D.R., Sullivan, T.J. and De Jong, C.R. 2005. Applied social research: a tool for the human services. $6^{\text {th }}$ ed. Australia: Thomson Brooks/Cole.

Motala, S. and Luxomo, V. 2014. Parental involvement and access to learning: a perspective from Gauteng and the Eastern Cape, South Africa. Southern African Review of Education (SARE), 20(2): pp.80-96.

Motshekga, A.M. 2015. Basic Education Budget Vote Speech for the 2015/16 financial year delivered by the Minister of Basic Education at the National Assembly in Cape Town on 06 May 2015. Available online:

http://www.education.gov.za/Newsroom/MediaReleases/tabid/347/ctl/Details/ $\underline{\mathrm{mid} / 1814 / \text { ItemID/3272/Default.aspx }}$

Republic of South Africa. 1996. Department of Basic Education. South African Schools Act 84 of 1996. Pretoria: Government Printer.

Republic of South Africa. 2001. Department of Basic Education. National Policy on Whole-School Evaluation. Government Gazette Vol.433, No.22512 of July 2001, Pretoria. 
Republic of South Africa. 2011. Department of Basic Education. National Curriculum Statement for Grades R-12. Pretoria: Government Printer.

Republic of South Africa. 2011. Department of Basic Education. National Curriculum and Assessment Policy Statement (CAPS). Available online at: http://www.education.gov.za/Curriculum/NCSGradesR12/tabid/419/Default.a $\underline{\mathrm{spx}}$

Republic of South Africa. 2012. Department of Basic Education. Guidelines Relating to Planning for Public School Infrastructure.

$<$ http://www.education.gov.za $>24$ October. Pretoria: Government Printer.

Republic of South Africa. 2013. Department of Basic Education. National Senior Certificate. Technical Report. Pretoria: Government Printer.

Republic of South Africa. 2010. Department of Basic Education. The Delivery Agreement for the Basic Education Sector. Outcome 1: Improved quality of basic education. Pretoria: Government Printer.

Republic of South Africa. 2015. Office of the Presidency. National Planning Commission. National Development Plan-2030. Our Future - Make it Work. Pretoria: Government Printer.

SA Breaking News. 2014. Over 10000 Unqualified Teachers in Public Schools in 2013.

$<$ http://www.sabreakingnews.co.za/2014/03/20/over-10-000-unqualified-teac hers-in-public-schools-in-2013> 22, March (2014).

SAS Institute Inc. 2004. SAS/STAT® 9.1 User's Guide. Cary, NC: SAS Institute Inc.

Shulruf, B. 2010. Do extra-curricular activities in schools improve educational outcomes? A critical review and meta-analysis of the literature. International Review of Education, 56: pp.591-612.

South African Council for Educators (SACE). 2000. Code of professional ethics. As defined in the South African Council for Educators Act No. 31 of 2000. 
Tikly, L. 2011. Towards a framework for researching the quality of education in low income countries. Comparative Education, 47(1): pp.1-23.

UNESCO's General Education Quality Analysis/Diagnosis Framework (GEQAF). 2015. Curriculum.

Available online:

http://www.unesco.org/new/en/education/themes/strengthening-education-sys tems/quality-framework/core-resources/curriculum/

Veriava, F. 2013. The 2012 Limpopo textbook crisis. A study in rights-based advocacy, the raising of rights consciousness and governance. Commissioned by Section 27, 5th Floor Braamfontein Centre, 23 Jorissen Street, Braamfontein, Johannesburg, 2001.

Western Cape Education Department. 2013. Media release: Background to the national quintile system. Statement by Minister Donald Grant, Minister of Education, Western Cape.

Xaba, M. I. 2012. A qualitative analysis of facilities maintenance - a school governance function in South Africa. South African Journal of Education, 32: pp.215-226.

Jan Heystek

School for Education Studies

North-West University

Potchefstroom

jan.heystek@nwu.ac.za

Linda Minnaar

Private Education Practitioner

$\underline{\text { lorinmin@gmail.com }}$ 
